\title{
PROBLEMATIKA PENGINTEGRASI NILAI-NILAI KEISLAMAN PADA PEMBELAJARAN IPA DI MI MIFTAHUL HUDA JEPARA
}

\author{
Laila Fajrin \\ UIN Sunan Kalijaga, Yogyakarta, Indonesia \\ 19204080002@student.uin-suka.ac.id \\ Muqowim \\ UIN Sunan Kalijaga, Yogyakarta, Indonesia \\ muqowimk@gmail.com
}

\begin{abstract}
This study aims to analyze the problems in the application of the integration of islamic values with science material at the elementary education level of Madrasah Ibtidaiyah and to contribute to the world of education related to the implementation of the integration of islamic values with related subjects. The research method used is qualitative descriptive analysis approach which is library research. Based on the data obtained, the researchers found several problems hampering the application of the integration of islamic values with MI science's material, namely the lack of quality humam resources, lack of facilities and infrastrukture, learning systems and devices as well as the provision of very basic material and only focused on the cognitive abilities of students. Therefore, researchers provide solutions for the procurement of learning modules, making learning concepts consisting of five points and conducting assessments that are in line with the concept of integration of islamic values and MI science sebjects. Research contributes in providing a detailed description of the application of the integration of islamic values with science to be used as a reference for the implementation of teaching and learning activities. In addition, the research carried out also helps scientists and academic activists who
\end{abstract}


have future challenges in formulating the concept of islamic education but do not override the values of general science.

Keywords: Integration; Islamic Value; Science at Madrasah Ibtidaiyah.

\begin{abstract}
Abstrak
Penelitian ini bertujuan untuk menganalisis problematika dalam penerapan integrasi nilai-nilai keislaman dengan materi IPA dijenjang pendidikan dasar Madrasah Ibtidaiyah serta memberikan kontribusi bagi dunia pendidikan terkait dengan pelaksanaan integrasi nilai keislaman dengan mata pelajaran terkait. Metode penelitian yang digunakan adalah kualitatif dengan pendekatan deskriptif analisis yang bersifat library research. Berdasarkan data yang diperoleh, peneliti menemukan beberapa problematika yang menghambat penerapan integrasi nilai-nilai keislaman dengan materi IPA MI, yaitu minimnya kualitas SDM, kurangnya sarana dan prasarana, sistem dan perangkat pembelajaran serta pemberian materi yang sangat dasar dan hanya difokuskan pada kemampuan kognitif peserta didik. Oleh sebab itu, peneliti memberikan solusi pengadaan modul pembelajaran, pembuatan konsep pembelajaran yang terdiri dari lima point dan melakukan penilaian yang selaras dengan konsep integrasi nilai keislaman dan mata pelajaran IPA MI. Penelitian ini juga berkontribusi dalam memberikan gambaran secara detail terkait penerapan integrasi nilai keislaman dengan ilmu pengetahuan untuk dijadikan acuan bagi terlaksananya kegiatan belajar mengajar. Selain itu, penelitian yang dilakukan juga turut serta membantu para ilmuan dan pegiat akademisi yang memiliki tantangan masa depan untuk merumuskan konsep pendidikan Islam tetapi tidak mengesampingkan nilai-nilai ilmu pengetahuan umum.
\end{abstract}

Kata Kunci: Integrasi; Nilai-nilai Keislaman; IPA di Madrasah Ibtidaiyah

\title{
A. Pendahuluan
}

Dalam dunia yang hampir seluruhnya berisi institusi pendidikan, kajian tentang integrasi ilmu pengetahuan dengan ilmu keislaman tentu menjadi pembahasan yang penting karena akan melahirkan pendidikan umum yang mengejawantahkan nilainilai keislaman. Pengintegrasian pendidikan dan nilai-nilai Islam dalam pengajaran dan pembelajaran ini tentu harus dilakukan 
tanpa membuat dikotomi pengetahuan. Dalam pandangan yang lebih luas, masyarakat masih beranggapan bahwa tidak terdapat keterkaitan antara ilmu pengetahuan umum dengan ilmu agama. Inilah salah satu bentuk dikotomi ilmu pengetahuan yang patut untuk diantisipasi dengan mengadakan pendidikan yang terintegrasi (Ikhwan, 2014).

Secara umum, manusia dapat berfikir dengan cara yang sama seperti yang telah dilakukan oleh manusia lain pada dua ratus tahun silam. Termasuk dalam memandang keilmuan dari sisi agama maupun ilmu umum. Agama menjadikan manusia memiliki keimanan sehingga hidup yang dijalani lebih terarah, memiliki moral dan etika serta berakhlak dan beradab. Sedangkan, sains atau ilmu umum memberikan sumbangsih pada tingkat pengetahuan manusia. Perkembangan sains menghasilkan temuan-temuan baru untuk mempermudah kehidupan manusia. Alhasil, setiap tahun perkembangan ilmu pengetahuan sangat masif terjadi, begitupun dalam dunia pendidikan (Teguh Wangsa, 2011).

Dalam penelitiannya (Yogiswari, 2020), menjelaskan pendapat seorang tokoh ilmuan dunia kelahiran Jerman yang bernama Albert Einstein yang mengatakan bahwa ilmu pengetahuan yang tidak didasari dengan agama akan lumpuh dan agama tanpa ilmu pengetahuan akan buta. Dari ucapannya, menggambarkan dengan jelas bahwa agama dan ilmu pengetahuan adalah dua hal yang berbeda tetapi memiliki peran yang kuat didalam kehidupan manusia dari zaman dahulu hingga sekarang. Dengan memahami keduanya melalui materi yang terintegrasi maka manusia dapat secara utuh menyempurnakan pengalaman dan pengetahuannya.

Dalam buku Pemikiran Al-Ghozali Tentang Pendidikan diterangkan bahwa Imam Al-Ghazali menjelaskan terkait pendidikan yang memiliki tujuan untuk mendekatkan diri kepada AllahSWT. Menurutnya, manusia dapatmelakukan taqorrubilallah apabila telah mendapatkan ilmu pengetahuan. Ilmu pengetahuan 
sendiri tidak akan pernah didapatkan oleh manusia tanpa melalui proses pembelajaran(Rus, 2009). Di negara Indonesia, tujuan pendidikan telah dituangkan dalam Undang-Undang Nomor 20 tahun 2003 tentang Sistem Pendidikan Nasional, Pasal I menyatakan bahwa, "Pendidikan adalah usaha sadar dan terencana untuk mewujudkan suasana belajar dan proses pembelajaran agar peserta didik secara aktif mengembangkan potensi dirinya untuk memiliki kekuatan spiritual keagamaan, pengendalian diri, kepribadian, kecerdasan, akhlak mulia, serta keterampilan yang diperlukan dirinya, masyarakat, bangsa dan negara" (Depdiknas, 2003). Sehingga penting kiranya untuk mengaplikasikan dengan cara mengintegrasikan materi pelajaran dengan nilai-nilai keislaman, utamanya pada mata pelajaran Ilmu Pengetahuan Alam (IPA).

Pembelajaran merupakan proses yang dilalui untuk meningkatkan mutu dan kompetensi lulusan dalam rangka pengembangan potensi diri (Helmawati, 2019). Sedangkan pembelajaran IPA adalah salah satu disiplin ilmu yang memiliki karakteristik khusus mempelajari tentang alam dan isinya, misalnya seperti peristiwa dan gejala-gejala yang muncul dialam dan bersifat objektif, nyata dan memiliki sebab-akibat (Samatowa, 2006). Mempelajari IPA bukan hanya mengkaji teori saja, ada yang lebih penting, yaitu terkait dengan bagaimana menerapkan sikap peserta didik untuk mencintai lingkungan, melestarikan alam dan mampu memaknai alam sesuai dengan nilai yang ada. Menurut Permendikbud Nomor 21 tahun 2016 tentang Standar Isi dijelaskan bahwa tujuan dari pembelajaran IPA di Indonesia salah satunya adalah supaya peserta didik memiliki keyakinan terhadap keteraturan alam ciptaan-Nya dan keagungan Tuhan Yang Maha Esa (Kemendikbud, 2016). Dengan demikian, pengintegrasian nilai-nilai keislaman dengan pembelajaran IPA sangat penting untuk diterapkan mulai dari level pendidikan terendah, yaitu MI/SD. Hal ini bertujuan untuk meningkatkan kompetensi intelektual dan spiritual peserta didik, sehingga 
peserta didik mampu mengenal, menjaga dan mencintai alam sejak dijenjang pendidikan dasar. Sebagaimana firman Allah SWT dalam al-Qur'an surat Al-A'raf ayat 56 yang berbunyi :

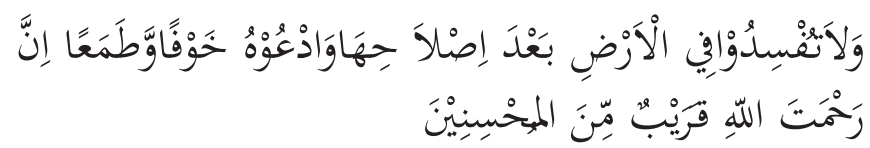

Ayat diatas menjelaskan bahwa Allah SWT melarang manusia berbuat kerusakan baik didarat, udara maupun dilaut. Sebab kerusakan itu akan membahayakan tatanan kehidupan manusia itu sendiri. Selanjutnya, Allah memerintahkan manusia untuk berdo'a kepada-Nya supaya mendapatkan nikmat dan manfaat yang besar (Kementrian Agama RI, 2013). Sebagai contoh, didalam materi pembelajaran IPA, peserta didik mengetahui macam-macam sumber energi, seperti matahari. Secara teoritis, peserta didik faham bahwa matahari merupakan sumber energi terbesar di bumi. Matahari mampu menghasilkan energi panas dan juga energi cahaya. Disamping itu, peserta didik juga merasakan manfaat dari matahari, diantaranya untuk menghangatkan badan dan mengeringkan pakaian. Dengan begitu, peserta didik memiliki rasa syukur dan meningkatkan ketakwaannya kepada Allah SWT yang telah menciptakan matahari. Makna integrasi nilai-nilai keislaman dengan pembelajaran IPA tidak hanya diukur dari tingkat kognitif yang dikuasai peserta didik saja.

Secara kognitif, anak-anak dapat memahaminya. Sayangnya, penguatan dalam ranah integrasi nilai-nilai keislaman ini kurang mendapatkan perhatian yang serius. Peserta didik dianggap mumpuni hanya dengan memahami teori atau materi. Keadaan ini pula yang menyebabkan pembelajaran IPA menjadi minim mutu dan kurang berbobot. Pelajaran yang disajikan juga sangat minim dari nilai-nilai spiritual, padahal nilai-nilai tauhid utamanya sangat relevan dipadukan dengan ilmu umum sebagai penguat akidah, tidak hanya dikaitkan dengan ilmu-ilmu agama. Tanpa 
disadari, ilmu umum mampu memberikan dampak destruktif dalam kehidupan manusia. Berangkat dari latar belakang inilah, penulis menganggap perlu untuk mengkaji lebih dalam khususnya di jenjang pendidikan islam dasar, yaitu Madrasah Ibtidaiyah (MI), terkait dengan masalah-masalah yang menghambat penerapan integrasi nilai-nilai keislaman dalam proses belajar mengajar mata pelajaran IPA kelas V di MI Miftahul Huda Jepara. Penelitian ini betujuan untuk menganalisis hambatan-hambatan dalam penerapan paradigma integrasi nilai-nilai keislaman dengan mata pelajaran IPA sehingga dapat memberikan solusi yang solutif bagi para pendidik serta memberi kontribusi nyata bagi dunia pendidikan dalam pelasanaan pembelajaran yang berbasis pada integrasi nilai-nilai keislaman dengan mata pelajaran terkait.

\section{B. Pembahasan}

\section{Paradigma Integrasi Nilai-Nilai Keislaman dengan Mata Pelajaran IPA MI}

Seorang tokoh bernama Captra dalam bukunya yang berjudul TaoofPhysics menyebutkan bahwa paradigma adalah sebuah asumsi dasar yang memerlukan sebuah bukti pendukung untuk asumsiasumsi yang ditegakkan dalam memberikan gambaran terhadap interpretasinya (Salim, 2006). Salah satu paradigma dari sebuah pengetahuan adalah penerapan pembelajaran integratif. Bruce Joice menjelaskan bahwa model pembelajaran integratif adalah sebuah gambaran pada lingkup pembelajaran yang mencakup prilaku atau cara guru pada saat menerapkan model pembelajaran tersebut. Dengan begitu, integrasi nilai dalam pembelajaran dapat dimaknai sebagai sebuah proses bimbingan melalui suri tauladan guru yang diorientasikan kepada penanaman nilai-nilai kehidupan yang mencakup nilai-nilai agama, budaya, etika dan estetika dengan tujuan mencetak peserta didik yang berakhlak, religius, berkarakter serta terampil dan mampu bermanfaat bagi diri sendiri dan orang lain (Calista, 2019). 
Secara lebih mudah, pembelajaran Integrasi dapat dipahami sebagai suatu konsep pendekatan pembelajaran yang digunakan untuk memberikan pengalaman belajar yang bermakna bagi peserta didik. Bermakna memiliki arti bahwa dalam pembelajaran peserta didik akan memahami konsep-konsep yang mereka pelajari melalui pengalaman langsung dan menghubungkannya dengan konsep-konsep lain yang mereka pahami. Pembelajaran integrasi secara efektif akan membantu menciptakan kesempatan yang luas bagi peserta didik untuk melihat dan membangun konsep-konsep yang saling berkaitan (Arisona, 2017).

Sedangkan, integrasi merupakan model pembelajaran yang mengelola dan mengorganisir pengajaran dengan proses yang sistematis dan memadukan berbagai faktor internal maupun eksternal. Dalam artikelnya, Aty Mulyani dkk, menjelaskan bahwa model pembelajaran terpadu atau integrasi dapat diterapkan pada pembelajaran apapun termasuk pembelajaran IPA yang dipadukan dengan nilai-nilai keislaman dan diajarkan didalam agama Islam (Aty Mulyani, 2018).

Nilai keislaman menjadi sebuah paradigma ideoligis bagi karakteristik peserta didik yang harus diintegrasikan pada mata pelajaran sehingga membangun karakter yang baik bagi peserta didik. Nilai-nilai islam terkandung didalam al-Qur'an yang merupakan landasan etik, sedangkan prakteknya dicerminkan dalam perilaku Rasulullah SAW sebagai uswatun hasanah. Meneladani Rasulullah SAW sama dengan menjalankan nilainilai keislaman. Nilai yang dapat diintegrasikan merupakan nilai akidah, syari'ah dan akhlak (Aziz, 2012). Pada mata pelajaran IPA kelas $\mathrm{V}$ tema 8 subtema 3 pembelajaran ke- 5 tentang pelestarian lingkungan. Output yang diharapkan tidak hanya sebatas mengerti teori, tetapi peserta didik diharapkan memiliki karakter menjaga lingkungan. Sebagaimana yang telah dijelaskan dalam al-Qur'an surat Ar-Rum ayat 41 : 


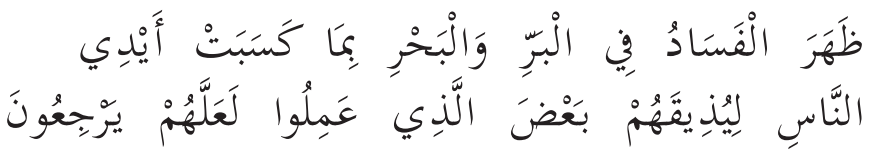

Artinya : "telah tampak kerusakan di darat dan di laut disebabkan karena perbuatan tangan manusia; Allah menghendaki agar mereka merasakan sebagian dari (akibat) perbuatan mereka, agar mereka kembali (ke jalan yang benar)" (Kementrian Agama RI, 2013).

Ayat diatas dapat dijadikan landasan dalam membentuk karakter menjaga kelestarian lingkungan yang dipelajari dalam pembelajaran IPA MI. Selain itu, pendidik juga dapat memaparkan terkait dengan temuan-temuan dari para intelektual muslim seperti Ar-Razi penemu sabun, Al-Khawarizmi penemu aljabar dan Al-Kindi penemu parfum. Semakin mempelajari ilmu pengetahuan alam, justru semakin membuka mata terhadap kebesaran dan kekuasaan Allah SWT yang telah menciptakan alam semesta ini. Hal ini seharusnya mampu meningkatkan keimanan dan kadar ketakwaan seseorang. Ilmu pengetahuan datangnya dari Allah SWT dan materi yang dikaji merupakan bagian dari kebesaran dan kemahakuasaan Allah SWT. Integrasi nilai keislaman dalam pembelajaran IPA dapat diwujudkan dengan pembelajaran dan bahan ajar yang terintegrasi. Disamping itu, persiapan dari guru sebagai seorang pendidik memiliki andil yang cukup besar dalam menyiapkan perangkat pembelajaran, Silabus, RPP, dan media pembelajaran (Aty Mulyani, 2018).

Hamzah menjelaskan dalam penelitiannya bahwa pengembangan bahan ajar pembelajaran IPA yang akan diintegrasikan dengan nilai-nilai keislaman memiliki tingkat efektivitas dan kemenarikan yang tinggi karena dapat disesuaikan dengan kebutuhan peserta didik. Selain itu, dengan pengintegrasian maka meningkatkan kebermaknaan materi pembelajaran (Hamzah, 2015). 


\section{Metode Penelitian}

Penelitian yang dilakukan menggunakan jenis penelitian kualitatif dengan pendekatan deskriptif analisis yang bersifat studi pustaka (library research). Penelitian kualitatif adalah jenis penelitian yang digunakan untuk meneliti objek secara alami, dalam hal ini peneliti sebagai instrumen kunci (Sugiyono, 2016). Studi pustaka yang dilakukan tidak disertai dengan uji empiris. Sumber penelitian ada dua, yaitu sumber primer yang berasal dari buku-buku maupun jurnal-jurnal online yang terakreditasi dan dipercaya kredibilitasannya sehingga mampu untuk menunjang hasil penelitian, serta sumber sekunder sebagai bahan pendukung yaitu hasil wawancara pada tanggal 27 Maret 2020 dengan guru kelas V MI Miftahul Huda Jepara yang bernama Bapak Sholikhin, S.Pd.. Objek penelitian adalah integrasi nilainilai keislaman pada mata pelajaran IPA di MI Miftahul Huda Jepara.

Metode pengumpulan data dilakukan dengan cara mengumpulkan literatur-literatur atau data penelitian yang berupa kepustakaan. Data-data diperoleh melalui buku-buku dan jurnal-jurnal online yang diakses melalui google scholar. Selanjutnya data yang diperoleh diolah dan dianalisis. Data yang disajikan berupa kata atau narasi deskriptif yang telah diolah dengan ringkas dan sitematis. Analisis data dilakukan dengan cara analisis isi (content analysis). Setelah data yang didapatkan selesai diolah barulah ditarik kesimpulan.

Secara lebih jelasnya, metode penelitian dapat disajikan dalam bagan sebagai berikut : 


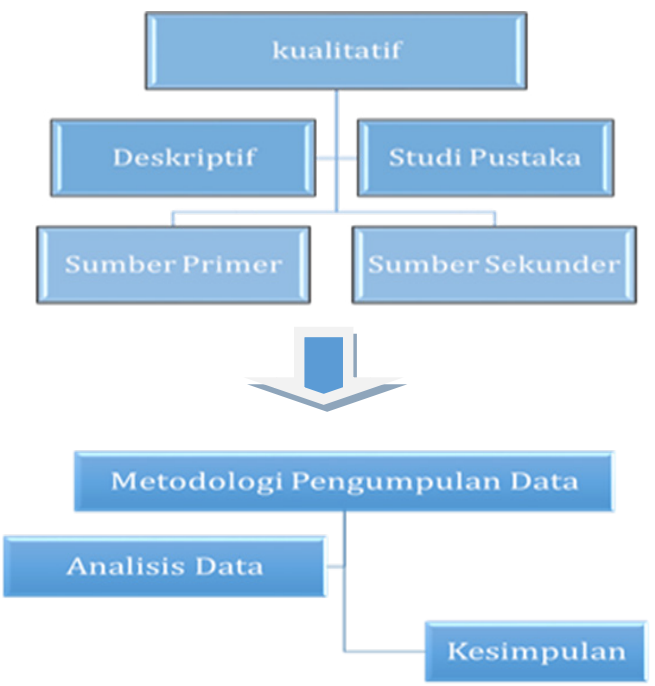

Gambar 1. Metode Penelitian

\section{Hasil Penelitian}

\section{a. Problematika Penerapan Integritas Nilai-Nilai Keislaman dengan Mata Pelajaran IPA MI}

Masa renaissance menjadi tanda kemunduran ilmu pengetahuan islam di abad 13-20 M. pada masa inilah ilmu pengetahuan di negara-negara barat berkembang pesat. Selain itu, muncul pula sekularisasi ilmu pengetahuan di barat yang mendapat pertentangan dari kaum gereja. Pertentangan ini membawa Galileo yang dipercaya sebagai pahlawan sekularisasi dihukum mati pada tahun $1633 \mathrm{M}$, sebab pendapatnya bertentangan dengan pandangan yang diimani gereja. Peristiwa inilah yang akhirnya memicu ilmu pengetahuan dipisahkan dari doktrin agama. Situasi ini memicu para cendekiawan muslim untuk kembali mengintegrasikan ilmu dan agama.

Usulan yang pertama kali diupayakan adalah islamisasi ilmu pengetahuan. Akan tetapi, tidak semua pemikir islam setuju, justru muncul dilematis dan 
perdebatan diantara para cendekiawan muslim. Tokohtokoh cendekiawan muslim yang memberikan sumbangsih pemikiran adalah Ismail Raji Al-Faruqi, Syed Muhammad Naquid AL-Attas, Fazlur Rahman dan Ziauddin Sardar (Fathul Mufid,2013). Fazlur Rahman, pengarangbuku Islam dan Modernity mengkritik dengan keras ide islamisasi ilmu pengetahuan yang diusung oleh tokoh-tokoh tersebut diatas, karena menganggap upaya yang dilakukan sebatas mengubah atau mengcounter, target yang ingin dicapai hanyalah produk yang tidak akan bertahan lama. Fazlur Rahman bahkan menjuluki tiga tokoh tersebut dengan zero nothing about islam dan mengusulkan ide baru yaitu islamisasi ilmuan.

Amin Abdullah merasa ide islamisasi ilmuan akan mengalami kesulitan untuk memadukan studi islam dan umum karena keduanya ingin saling mengalahkan. Oleh karenanya, Amin Abdullah mengusulkan pendekatan integratif-interkonektif untuk memahami kompleksitas fenomena kehidupan dan merangkul berbagai disiplin keilmuan baik agama, sosial, humaniora, maupun kealaman. semua disiplin ilmu tidak dapat berdiri sendiri, butuh kerjasama dan saling melengkapi (Fathul Mufid, 2013). Pendekatan integrasi-interkoneksi tidak serta merta saling melumatkan, tetapi merupakan usaha untuk meleburkan antara ilmu agama dan ilmu umum.

Sayangnya, apa yang digaungkan dan disetujui oleh berbagai kalangan ini belum maksimal diterapkan dalam dunia pendidikan khususnya pendidikan dasar seperti SD/MI. Permasalahan-permasalahan yang dapat dianalisis bermunculan, mulai dari sisi internal maupun eksternal. Padahal telah jelas diuraikan dalam islam tentang tiga dimensi keislaman, yaitu iman, islam dan ihsan. Pada tahap iman berarti meyakini dengan sepenuh hati tentang keberadaan Allah SWT. Setelah yakin dan percaya, tahap 
kedua adalah islam yang bermakna patuh menjalankan syariat agama. Tahap ketiga adalah ihsan yaitu aktualisasi diri yang didasarkan kepada Allah SWT. Tiga dimensi ini dapat menjadi dasar integrasi ilmu pengetahuan dengan nilai keislaman (Fathul Mufid, 2013).

Mengintegrasikan ilmu pengetahuan IPA yang membahas tentang kealaman dengan nilai-nilai keislaman memang butuh persiapan. Penulis mencoba menganalisis problematika yang dialami guru kelas V di MI Miftahul Huda Jepara dalam menerapkan integrasi nilai-nilai keislaman dengan materi IPA. Data yang diperoleh oleh peneliti berdasarkan hasil wawancara pada tanggal 27 Maret 2020. Setelah data hasil wawancara dan dokumentasi dianalisis, maka penulis merumuskan beberapa point dari problematika penerapan integrasi nilai-nilai keislaman dengan mata pelajaran IPA MI.

Promblematika yang dialami oleh guru kelas V di MI Miftahul Huda Jepara berdasarkan hasil wawancara dan pemerolehan dokumentasi adalah sebagai berikut :

Tabel 1. Problematika Penerapan Integrasi

Kualitas sumber daya manusia yang masih rendah dan perlu ditingkatkan. Masih ada SDM yang gagap terhadap penerapan 1. integrasi, sehingga kesadaran pada pentingnya integrasi nilainilai keislaman minim. Ada pula SDM yang kaya ilmu umum tetepi tidak kaya ilmu agama tau sebaliknya.

Sarana dan prasarana yang belum memadai. Termasuk sumber 2. bacaan bagi peserta didik. Meski tersedia perpustakaan, tetapi subsidi buku-buku terupdate dan yang mengarahkan siswa untuk gemar membaca ilmu-ilmu yang bernuansa agama masih rendah. 
Sistem dan perangkat pembelajaran kurang mendukung dalam menerapkan integrasi nilai-nilai keislaman dengan materi IPA

3. MI. Guru cenderung mendikotomikan ilmu umum dan ilmu agama. Tidak adanya perangkat pembelajaran yang disipakan dan dirancang khusus untuk mengintegrasikan nilai keislaman dengan mata pelajaran IPA MI

Pemberian materi keagamaan untuk peserta didik sangat dasar

4. dan masih kurang dalam menangkal dampak-dampak negatif yang mempengaruhi sikap, pola pikir dan karakter peserta didik. Disamping itu, guru cenderung fokus pada sisi kognitif saja.

Dari problematika diatas, penulis memberikan sulusi yang sekiranya dapat dilaksanakan dan memiliki kebermanfaatan dalam proses pembelajaran yang diintegrasikan dengan nilai keislaman. Pertama, pengadaan modul. Modul adalah sarana pembelajaran yang berisi materi, metode, dan evaluasi yang dirancang secara sistematis dan menarik guna mencapai kompetensi yang diharapkan. Modul pembelajaran harus mampu memerankan fungsi dan peranannya dalam pembelajaran (Yuliawati, 2013). Selain mempersiapkan modul yang baik, guru juga menyusun konsep pembelajaran.

Konsep pembelajaran yang berasal dari perangkat sistem mata pelajaran IPA untuk diintegrasikan dengan nilai-nilai keislaman diantaranya adalah : (Arisona, 2017)

1) Menentukan materi yang akan diintegrasikan

2) Mempelajari Kompetensi Inti (KI) dan Kompetensi Dasar (KD) dari materi yang akan diintegrasikan

3) Melakukan identifikasi terhadap KD dalam KI yang berpotensi untuk dipadukan

4) Membuat indikator pencapaian

5) Menyusun silabus da RPP pembelajaran integrasi

Contoh kompetensi dasar IPA yang diintegrasikan dengan nilai-nilai keislaman pada kurikulum 2013 adalah sebagai berikut : 
Tabel 2. Perangkat Pembelajaran Integrasi IPA-PAI

\begin{tabular}{|c|c|}
\hline IPA & PAI \\
\hline $\begin{array}{l}\text { KI.2 Menunjukkan perilaku jujur, disiplin, } \\
\text { tanggung jawab, santun, percaya diri, } \\
\text { peduli, dan bertanggung jawab dalam } \\
\text { berinteraksi dengan keluarga, teman, } \\
\text { guru tetangga, dan negara }\end{array}$ & $\begin{array}{l}\text { KI } 2 \text { Menunjukkan perilaku jujur, } \\
\text { disiplin, tanggung jawab, santun, } \\
\text { peduli, dan percaya diri dalam } \\
\text { berinteraksi dengan keluarga, } \\
\text { teman, dan guru }\end{array}$ \\
\hline
\end{tabular}

KD 3.8 Menganalisis siklus air dan KD 2.8 Menunjukkan sikap dampaknya pada peristiwa di bumi sederhana dalam kehidupan serta kelangsungan makhluk hidup sehari-hari.

Materi : Usaha Pelestarian Lingkungan Materi : Makna hidup sederhana

Integrasi nilai-nilai keislaman yang dapat dilakukan adalah dengan memasukan nilai-nilai Islam untuk berperilaku sederhana yang terkandung dalam Q.S Al-Qashash ayat 79-82, dan mengaitkannya dengan cerita Karun yang suka kemegahan dan mementingkan duniawi, serta sombong sebagai makhluk ciptaan Allah SWT. Sehingga Allah SWT memperingatkannya dengan membenamkan rumah dan hartanya, serta tidak ada yang dapat menolongnya dari azab tersebut. Kandungan makna ini dapat dimasukkan dalam mata pelajaran IPA materi usaha pelestarian lingkungan yang membahas tentang air dan dampaknya bagi bumi serta kelangsungan hidup makhluk hidup. Dengan berperilaku boros, berlebihlebihan dalam segala hal dan sombong menjadikan pribadi yang tidak baik. Kemudian, peserta didik dapat diminta untuk menanggulangi permasalahan lingkungan hidup dengan mengajak siswa menjaga lingkungan sekitar, seperti tidak membuang sampah sembarangan, bergotongroyong membersihkan lingkungan sekolah, tidak mencemari air dan mencoba mencari solusi permasalahan lingkungan di sekitar mereka melalui pembelajaran IPA. 
Dalam penelitiannya Zarima Zain dan Rian Vebrianto menjelaskan penilaian yang dilakukan untuk mata pelajaran yang diintegrasikan dengan nilai-nilai keislaman, yaitu dengan cara menyeluruh dan utuh. Contohnya, pada ranah afektif maupun kognitif yang belum memiliki cara penilaian baku. Penilaian dapat dilakukan dengan melihat keberhasilan belajar peserta didik dalam proses pembelajaran integrasi. Ranah kognitif dilakukan dengan evaluasi umum seperti pemberian soal (ulangan harian, PAT/PAS). Ranah afektif dan psikomotok dilakukan terpisah, misalnya pada materi Usaha Pelestarian Lingkungan, penilaian dapat dilihat dari sikap kepedulian peserta didik ketika melihat sampah, menggunakan air, dan membuang sampah. Untuk ranah psikomotorik dapat dilihat dari usaha peserta didik mendaur ulang limbah menjadi suatu produk yang bermanfaat dan bernilai (Zain \& Vebrianto, 2017).

Hal demikian sejalan juga dengan tuntutan di era revolusi industri 4.0, pendidikan di Indonesia dituntut ikut mengalami perubahan menuju pendidikan berbasis digital yang mampu bergerak cepat mengikuti perkembangan. Melatih peserta didik untuk berfikir tingkat tinggi (higher order thinking skills) guna bekal hidup di masyarakat (Sani, 2019). Sebagaimana dijelaskan sebelumnya, bahwa inilah langkah yang diambil supaya peserta didik mampu mengambil keputusan, berfikir kritis, reflektif, dan faham dengan pengetahuan awal sehingga menjadi lulusan yang siap mengatasi masalah didunia nyata serta tetap berpegang teguh pada nilai-nilai keislaman.

\section{Simpulan}

Penerapan itegrasi nilai-nilai keislaman dengan mata pelajaran IPA ditingkat Madrasah Ibtidaiyah adalah satu hal yang 
penting untuk dilakukan dan mendapatkan perhatian serius, karena MI merupakan pendidikan dasar bagi peserta didik. Integrasi yang dilakukan hendaknya berdasar pada al-Qur'an maupun hadist yang relevan. Didalam penerapannya, ada empat problematika yang dihadapi oleh duru selaku pendidik dalam menerapkan integrasi nilai keislaman dengan materi IPA. problematika tersebut berkaitan dengan kualitas sumber daya manusia, sarana dan prasarana, sistem dan perangkat pembelajaran serta materi yang disampaikan. Solusi yang dapat dilakukan untuk mengatasi problematika tersebut adalah dengan membuat modul pembelajaran integrasi, mempersiapkan konsep pembelajaran sekaligus penilaiannya. Harapannya, dengan adanya penerapan integrasi nilai-nilai keislaman dengan materi IPA, guru tidak hanya terfokus pada ranah kognitif saja. Ada yang lebih penting dari itu, yaitu tauhid, akhlak dan karakter baik peserta didik. Penelitian ini memberikan kontribusi di dunia pendidikan dengan menawarkan gambaran secara detail terkait penerapan integrasi nilai keislaman dengan ilmu pengetahuan yang dijadikan acuan bagi terlaksananya proses kegiatan belajar mengajar di lembaga pendidikan. Selain itu, juga membantu para ilmuat dan civitas academika yang aktif meneliti dan mengembangkan pendidikan serta memiliki tantangan masa depan bagi perbaikan dan perumusan konsep pendidikan Islam tanpa harus meninggalkan nilai-nilai ilmu pengetahuan umum yang ada. 


\section{DAFTAR PUSTAKA}

Arisona, R. D. (2017). INTEGRASI NILAI-NILAI ISLAM DALAM PEMBELAJARAN IPS DI MI. PROCEEDINGS ANCOMS 2017, 110-112, 329-337.

Aty Mulyani, dkk. (2018). Integrasi Ilmu Pengetahuan Alam dan Nilai-nilai Islam untuk Pembangunan Karakter Peserta Didik di Madrasah Aliyah. JEMST; Journal Of Education in Mathematics, Science, and Technology, 1(1), 16-19. http:// jemst.ftk.uinjambi.ac.id/

Aziz, H. . (2012). Pendidikan Karakter Berpusat Pada Hati: Akhlak Mulia Pondasi Membangun Karakter Bangsa. Al-Mawardi.

Calista, W. (2019). Integrasi Mata Pelajaran IPA Dengan Nilai-Nilai Islam Melalui Pendekatan Bayanidi Kelas IIIC MI Negeri 1 Yogyakarta. JIP: Jurnal Ilmiah PGMI, 5(2), 223-236.

Depdiknas. (2003). UU RI Nomor 20 Tahun 2003 Tentang Sistem Pendidikan Nasional, Jakarta: Dirjen Pendidikan Dasar dan Menengah.

Fathul Mufid. (2013). Integrasi Ilmu-Ilmu Islam. Equilibrium, 1(1), 55-71. http://journal.stainkudus.ac.id/index.php/ equilibrium/article/view/200

Hamzah, F. (2015). Studi Pengembangan Modul Pembelajaran Ipa Berbasis Integrasi Islam - Sains Pada Pokok Bahasan Sistem Reproduksi Kelas Ix Madrasah Tsanawiyah. Adabiyah : Jurnal Pendidikan Islam, 1(1), 41-54. https://doi.org/10.21070/ ja.v1i1.163

Helmawati. (2019). Pembelajaran dan Penilaian Berbasis HOTS. PT Remaja Rosdakarya.

Ikhwan, A. (2014). Integrasi Pendidikan Islam (Nilai-Nilai Islami dalam Pembelajaran). Ta'allum: Jurnal Pendidikan Islam, 2(2). https://doi.org/10.21274/taalum.2014.2.2.179-194 
Kemendikbud. (2016). Permendikbud Nomor 21 Tahun 2016 Tentang Standar Isi untuk Satuan Pendidikan Dasar dan Menengah, Jakarta: Dirjen Pendidikan Dasar dan Menengah.

Kementrian Agama RI. (2013). Al-Qur'an Al-Karim dan Terjemahannya. Halim.

Rus, A. I. (2009). Pemikiran Al-Ghazali Tentang Pendidikan. Pustaka Pelajar.

Salim, A. (2006). Teori dan Paradigma Penelitian Sosial. Tiara Wacana.

Samatowa. (2006). Bagaimana Membelajarkan IPA di Sekolah Dasar. Direktorat Jendral Tinggi Departemen Pendidikan Nasional.

Sani, R. A. (2019). Pembelajaran Berbasis HOTS (Higher OrderThinking Skills). In Pembelajaran Berbasis HOTS (Higher OrderThinking Skills). Tsmart.

Sugiyono. (2016). Metode Penelitian Pendidikan (Pendekatan Kuantitatif, Kualitatif dan R\&D). Alfabeta.

Teguh Wangsa. (2011). Filsafat Pendidikan; Mazhab-Mazhab Filsafat Pendidikan. Ar-Ruz Media.

Yogiswari, K. S. (2020). Komparasi Pandangan Filsafat Agama Albert Einstein dan Holmes Rolston III. Sanjiwani: Jurnal Filsafat, 9(1), 53. https://doi.org/10.25078/sjf.v9i1.1612

Yuliawati, F. dkk. (2013). PENGEMBANGAN MODUL PEMBELAJARAN SAINS BERBASIS INTEGRASI ISLAM-SAINS UNTUK PESERTA DIDIK DIFABEL NETRA MI/SD KELAS 5 SEMESTER 2 MATERI POKOK BUMI DAN ALAM SEMESTA. Jurnal Pendidikan IPA Indonesia, 2(2), 169-177.

Zain, Z., \& Vebrianto, R. (2017). Integrasi Keilmuan Sains Dan Islam Dalam Proses Pembelajaran Rumpun IPA. Seminar Nasional Teknologi Informasi, Komunikasi Dan Industri (SNTIKI) 9, 18-19. 